\title{
Improving Healthcare Disparities of African American Males through Healthcare Leadership
}

\author{
Javis M. Knott ${ }^{*}$, Angelina Knott ${ }^{2}$ \\ ${ }^{1}$ Assistant Professor; School of Public Health, Jackson State University, USA \\ ${ }^{2} \mathrm{MS}, \mathrm{CPC}$, Healthcare Data Source Management, USA
}

\author{
Article Details \\ Article Type: Mini Review \\ Received date: $29^{\text {th }}$ November, 2017 \\ Accepted date: $23^{\text {rd }}$ December, 2017 \\ Published date: $11^{\text {th }}$ January, 2018
}

"Corresponding Author: Javis M. Knott, School of Public Health, Assistant Professor; Jackson State University, USA. E-mail. javis.m.knott@jsums.edu

Citation: Knott JM, Knott A (2018) How safe is social casino gambling for elderly women? J Pub Health Issue Pract 2: 107. https://doi.org/10.33790/jphip1100107.

Copyright: $\mathbb{C} 2018$, This is an open-access article distributed under the terms of the Creative Commons Attribution License 4.0, which permits unrestricted use, distribution, and reproduction in any medium, provided the original author and source are credited.

\begin{abstract}
The success rate for African American male students has surged as it relates to educational reform initiatives that not only challenge traditional structures of education but also mandate that policymakers, administrators, and educators craft new models to ensure success [1]. According to the US Department of Education, African American males constitute only $18 \%$ of the nation's total student population enrolled in public schools. The Kaiser Foundation found that there is a link between socioeconomic status and health. The study found that on average, individuals with more education have more income and tend to have better access to health care and better health outcomes than those with less education and income. The study also found that $38 \%$ of African American men between the ages of 16-24 with a high school diploma were enrolled in college compared to $67 \%$ of Asians and non-whites. Of the percentage of African American men enrolling in college only a few enroll in healthcare programs. The shortage of African American males pursuing careers in healthcare could be directly related to the disparate number of African American males enrolled in college. Therefore, continued efforts must be made to first, increase the college enrollment for African American men, and second, increase the number of African American men enrolling in healthcare programs which will in-turn increase the number of African American males in healthcare leadership positions. An increase in the number of African American men in healthcare leadership positions will aid in addressing health disparities such as hypertension, diabetes, and cardiovascular health in African American men by bringing a cultural awareness of how to get other African American men better access to healthcare. To assist with improving the number of African American men in healthcare leadership positions, focus needs to be placed on developing programs designed to attract and prepare African American males for healthcare leadership positions [2].
\end{abstract}

There has been focus on improving college preparation for underrepresented students including African American males for college and beyond. According to the Journal of African American Males in Education, college preparation programs can improve outcomes by: (a) increasing the enrollment rates while promoting college attendance, college awareness, and college exposure, (b) build participants' self-esteem and provide role models and mentorship, and (c) improve academic skills and preparation of students. The study also found that $57 \%$ of the college preparation programs are based at colleges and universities. Additionally, according to a study conducted by the Brookings Institute in 2011 on Healthcare Diversity Leadership, minorities account for 98 percent population growth in the nation's largest metro areas during the last decades. Therefore, it is even more important that healthcare leaders embrace cultural competency and recruit diverse leaders to better serve their patients. The study suggests that the pool of diverse candidates can improve by reaching out to students at a young age and attracting them to the field. Research suggests that African American males with a BS in healthcare administration, coupled with mentoring and internships can be successful in pursuing a career as a healthcare administrator which will allow them to be in positon to bring resources to address the healthcare disparities of African American males in their communities.

According to a study done by the Foundation of the American College of Healthcare Executives, most healthcare executives obtained their undergraduate degree in healthcare administration. Therefore, a BS degree in a Healthcare Administration program is an important step for African American males to become successful in a career as a healthcare administrator. In order to complete the BS degree in healthcare administration, students are required to do an internship before graduating. An internship/fellowship proved to be an integral key when it came down to finding employment for healthcare executives. Mentorship is also important when it comes to being a successful healthcare administrator. The study stated that a majority of mentors for healthcare administrators were white males; therefore, it would also be important that faculty at colleges and universities include African American males with experience in healthcare management in an effort to help close the diversity gap. Mentorship is an integral part to ensuring the academic success of healthcare administrator students [3].

\section{Project Description}

A successful strategy will be to set up programs using data that has proven to be successful in recruiting, mentoring, and advising African American males on how to matriculate in order to obtain a 
bachelor's degree. The program will focus on recruiting African American males from health sciences programs at both high school and community colleges. The students, once recruited, will be assigned an advisor to guide them in the program and a mentor who will also provide the student a partner who has experience in leadership in healthcare administration. The students will also be assigned internships in which they will be paired with African American male healthcare professionals in the field. The programs shall provide the students with an IPad which will allow them to have access to technology that will enable them to do their work. Finally, students should be required to join the American College of Healthcare Executives (ACHE) [4].

\section{Recruiting}

Research suggests that to improve minority student enrollment in healthcare administration is to recruit them while they are young to attract them to the field. Therefore, a successful program shall focus on recruiting African American male students from the health sciences programs from the local high schools and community colleges.

\section{Advising}

The adviser plays an important role to the African American males participating in the program to ensure their success in the program. The advisor should have experience in healthcare administration both clinically and educationally and should be strong in advising students on how to succeed in healthcare leadership programs. Therefore, he/ she will advise the African American males by assisting them with their curriculum, meeting with them to discuss their status in their classes, and making sure they have all the necessary materials for class such as books, supplies, etc. The advisor will also communicate with the participant's faculty so that he can keep track of their progress in class. If the students need extra assistance with tutoring for example, the advisor will assist the participants with tutoring.

The advisor will require the participants to join the American College of Healthcare Executives (ACHE) organization, in which membership gives participants the opportunity to:

- Be among leaders in healthcare management

- Grow professionally and excel in their job

- Enjoy greater satisfaction and career potential

- Contribute to and give back to the profession

\section{Mentoring}

One of the major findings associated with not having a greater number of African American males in health- care leadership positions is the lack of African American mentors. Research suggests that more minorities will advance into healthcare leadership positions if they had access to more mentoring programs. The programs will expose young African American males to healthcare careers, sensitizing management, developing cultural sensitivity initiatives, and communicating diversity initiatives to employees.

The national study on healthcare executives showed that more than eighty percent of the participants in the study stated they had a mentor who helped guide them in their career. The study also found that more than 80 percent of healthcare executives had a mentor who was white regardless of their race which suggest that more programs need to be offered that will allow African American male's access to mentors who are African Americans. Therefore, programs will need to assign mentors to each of the participants in the program. The mentors will come from different spectrums of healthcare in that surrounding area. The mentor role in the program will be to assist the student participants in understanding and accessing the healthcare leadership field. The participants will be assigned mentors who will serve as their liaison at the facility in which they will also do their internships. Each participant will be required to spend an assigned amount of time at the facility with their mentors shadowing the mentor and attending meetings. The idea is for them to gain exposure to real hands on experience from the mentors. Not only will the shadowing give the participant real life experience, it will also give them exposure and networking opportunities. The relationship developed between the mentor and the mentee will also allow for a future resource for the mentee for continued guidance throughout their healthcare career.

\section{Conclusion}

With the link between socioeconomic status and health being well established, it is very important that programs are designed to focus on improving educational outcomes of African American males in programs that will enable them to address the healthcare disparities of African American males. It is important to have more African American males in leadership positions because they will be able to bring attention and resources to ad- dress the crisis in health disparities in African American men and boys. To assist with improving this disparity, focus needs to be placed on developing programs designed to attract and prepare African American males for healthcare leadership positions. A successful strategy will be to set up programs using data that has proven to be successful in recruiting, mentoring, and advising African American males on how to matriculate in order to obtain a bachelor's degree.

\section{References}

1. Allen A, Lewis C, Scott L (2014) Dispelling Disparities for African American Male Students: A Review of Three Successful Charter School Models. J Afr Am Males in Edu. Spring 5.

2. American College of Healthcare Executives (2008) A Racial/ Ethnic Comparison of Career Attainments in Healthcare Management; Chicago.

3. The Henry J. Kaiser Family Foundation (2007) The Health Status of African American Men in the United States. Race, Ethnicity, \& Healthcare.

4. Kieffer W (2011) Building the Business Case. Healthcare Diversity Leadership. A national Survey report. Leaders Connecting Leaders 